О.С. Никоненко , А.О. Никоненко ${ }^{2}$, К.О. Чмуль ${ }^{2,3}$, В. В. Осауленко $0^{1,3}$ 'Державний заклад МОЗ України «Запорізька медична академія післядипломної освіти» ²Запорізький державний медичний університет ${ }^{3}$ Комунальне некомерційне підприємство «Запорізька обласна клінічна лікарня» Запорізької обласної ради

\title{
Оцінка якості життя пацієнтів з ішемічною хворобою серця з порушенням метаболізму вітаміну D та гомоцистеїну у віддалений післяопераційний період після аортокоронарного шунтування
}

Мета - оцінити динаміку якості життя у пацієнтів з ішемічною хворобою серця з порушенням метаболізму вітаміну D та гомоцистеїну після аортокоронарного шунтування (АКШ). Об'єкт і методи дослідження. АКШ проведено 126 пацієнтам з ішемічною хворобою серця. Опитувальник якості життя SF-36 пацієнти заповнювали при госпіталізації та через 6 і 12 міс спостереження після операції. Результати. У пацієнтів після АКШ, які отримували додатково метаболічну терапію, зазвичай не виникало рецидивів стенокардії, поліпшення якості життя зберігалось як в ранні, так і у віддалені терміни (до 3 років спостереження). У пацієнтів із рецидивом стенокардії після АКШ як в доопераційний, так і у віддалений періоди, показники якості життя значно відрізнялися від рівня ідеального здоров'я. Найбільш значущо були порушені показники психічного здоров'я, фізичного функціонування та сфери соціальних взаємин. Висновки. У пацієнтів після АКШ опитувальник SF-36 може забезпечувати надійну та сприйнятливу оцінку якості життя. Пацієнтам, які перенесли хірургічне втручання на судинах серця, необхідна корекція метаболічних порушень та порушень ліпідного обміну. Починати корекцію метаболічних порушень потрібно відразу після операції.

Ключові слова: ішемічна хвороба серця, гомоцистеїн, вітамін D, аортокоронарне шунтування, SF-36.

\section{Вступ}

Серцево-судинні захворювання - провідна причина смертності та інвалідності населення в усьому світі. Протягом останніх 10 років смертність від цих захворювань зросла на 12,5\% (GBD 2015 Mortality and Causes of Death Collaborators, 2016).

На сьогодні наявні два основні види лікування хворих на ішемічну хворобу серця (IXC): реваскуляризація міокарда, або стентування коронарних артерій, та консервативна терапія, спрямована на нормалізацію судинного тонусу, скорочувальної функції міокарда, корекцію метаболічних порушень (гіпергомоцистеїнемія (ГГЦ), гіповітаміноз D) тощо (Гандзюк В.A., 2014; Windecker S. et al., 2014). Аортокоронарне шунтування (АКШ) дозволяє покращити коронарний кровообіг, який порушується при різних видах IXC. Однак його ефективність може обмежуватися розвитком рестенозування за рахунок проліферації та міграції гладком'язових клітин (Montalescot G. et al., 2013).

Важливим чинником визначення тяжкості стану та подальшого лікування пацієнтів із IXC є оцінка якості життя (ЯЖ). Одним із найважливіших завдань та критеріїв оцінки ефективного лікування є прагнення покращити ЯЖ пацієнтів.

Мета - оцінити динаміку ЯЖ у пацієнтів із IXC з порушенням метаболізму вітаміну D та гомоцистеїну (ГЦ) після хірургічного лікування.

\section{Об 'єкт і методи дослідження}

За період з вересня 2017 р. по липень 2019 р. на кафедрі госпітальної хірургії Запорізького державного медичного університету у відділенні кардіохірургії Комунального некомерційного підприємства «Запорізька обласна клінічна лікарня» Запорізької обласної ради проведено АКШ 126 пацієнтам із ІХС. Зі стаціонару виписаний 121 (96,03\%) пацієнт, якому виконано АКШ. 3i 100 (82,6\%) виписаних пацієнтів із порушенням метаболізму ГЦ та вітаміну D під спостереженням у віддалений період перебували 54 (54,0\%) (табл. 1).
Хворих розподілили на дві групи: 1 -ша $(n=48)-$ пацієнти, які приймали метаболічну терапію після АКШ, та 2-га (n=6) - які самостійно припинили застосування препаратів після АКШ (табл. 1).

Корекцію метаболічних порушень після хірургічного втручання починали відразу після відновлення ентерального харчування. Терапію рекомендували продовжувати протягом 3-4 міс після виписки з подальшим контролем рівнів ГЦ та вітаміну D. У відда-

Таблиця 1. Демографічні та клінічні показники у порівнюваних групах ( $n=54)$

\begin{tabular}{|c|c|c|}
\hline Показник & 1-ша група ( $n=48)$ & 2-га група $(n=6)$ \\
\hline Вік, років & $59,33 \pm 5,4$ & $58,94 \pm 6,8$ \\
\hline Чоловіки, n (\%) & $44(91,7)$ & $5(83,3)$ \\
\hline Індекс маси тіла, кг/м² & $29,29 \pm 4,34$ & $28,89 \pm 5,54$ \\
\hline Гіпертонічна хвороба, n (\%) & $48(100,0)$ & $6(100,0)$ \\
\hline \multicolumn{3}{|l|}{ Стабільна стенокардія, n (\%): } \\
\hline • відсутня & $5(10,4)$ & - \\
\hline • ॥ функціональний клас & $23(47,9)$ & - \\
\hline • III функціональний клас & $20(41,7)$ & $1(16,6)$ \\
\hline • IV функціональний клас & - & $1(16,6)$ \\
\hline Нестабільна стенокардія, n (\%) & - & $4(66,7)$ \\
\hline Післяінфарктний кардіосклероз, n (\%) & $45(93,7)$ & $5(83,3)$ \\
\hline Цукровий діабет, n (\%) & $7(14,6)$ & $3(50,0)$ \\
\hline \multicolumn{3}{|l|}{ Серцева недостатність, n (\%): } \\
\hline - І стадія & $19(39,6)$ & - \\
\hline - ॥А стадія & $29(60,4)$ & $4(66,7)$ \\
\hline - ॥Б стадія & - & $2(33,3)$ \\
\hline \multicolumn{3}{|l|}{ Скарги: } \\
\hline • загрудинний біль & - & $6(100,0)$ \\
\hline • задишка & $3(6,25)$ & $5(83,3)$ \\
\hline • набряки нижніх кінцівок & $12(25,0)$ & $5(83,3)$ \\
\hline Гіперхолестеринемія, n (\%) & $4(8,33)$ & $2(33,3)$ \\
\hline \multicolumn{3}{|l|}{ ГГЦ, мкмоль/л } \\
\hline$\cdot \mathrm{n}(\%)$ & $2(4,17)$ & $6(100,0)$ \\
\hline • середні показники & $9,25 \pm 1,43$ & $21,85 \pm 9,64^{*}$ \\
\hline \multicolumn{3}{|l|}{ Дефіцит вітаміну D, нг/мл } \\
\hline$\cdot \mathrm{n}(\%)$ & $9(18,75)$ & $6(100,0)$ \\
\hline • середні показники & $36,92 \pm 7,90$ & $19,67 \pm 6,43^{*}$ \\
\hline
\end{tabular}

${ }^{*}<<0,05$ (достовірна різниця між 1-ю та 2-ю групами). 
лений післяопераційний період проведено порівняльну оцінку Яж пацієнтів із ГГЦ та дефіцитом вітаміну D до та після AКШ із призначенням метаболічної медикаментозної терапії та пацієнтів, які самостійно відмінили застосування деяких препаратів після АКШ. Оцінку показників ЯЖ здійснювали до та через 6 і 12 міс після реваскуляризації міокарда методом анкетування за допомогою опитувальника SF-36 Health Status Survey (Ware J.E. et al., 1993). Опитувальник SF-36 включав аналіз фізичного функціонування (Physical Functioning - PF), рольового функціонування, зумовленого фізичним станом (Role-Physical Functioning - RP), інтенсивності болю (Bodily pain - ВP), загального стану здоров'я (General Health - GH), життєвої активності (Vitality - VT), соціального функціонування (Social Functioning - SF), рольового функціонування, зумовленого емоційним станом (Role-Emotional -RE) та психологічного здоров'я (Mental Health - MH) - як компонентів фізичного та психічного здоров'я.

Більшість даних обробляли непараметричними методами з використанням пакета статистичних програм «Excel», «Statistica 6.0". Статистичний аналіз результатів проводили за допомогою комп'ютерної програми статистичної обробки даних у вигляді середніх значень ( $\mathrm{M} \pm \mathrm{m})$, непараметричних критеріїв у вигляді Ме (25-75\%). Для оцінювання значущості відмінностей кількісних параметрів між двома незалежними вибірками використовували критерій Манна - Уїтні. Достовірність відмінностей у групах прийнята при рівні статистичної значущості $p<0,05$.

\section{Результати та їх обговорення}

Як видно (див. табл. 1), більшість пацієнтів 2-ї групи $(66,7 \%)$ мали нестабільну стенокардію та серцеву недостатність ІІА та ІІБ стадії у 66,7 та 33,3\% випадків відповідно. Також у цій групі спостерігали достовірно вищі показники рівня ГЦ - 9,25 1 ,43 та $21,85 \pm 9,64$ мкмоль/л відповідно $(p<0,05)$. Середні показники рівня вітаміну D у досліджуваних групах становили $36,92 \pm 7,90$ та 19,67士6,43 нг/мл відповідно.

Пацієнти 2-ї групи з клінічною картиною стенокардії не застосовували деяких препаратів, рекомендованих при виписці з відділення. Так, 2 пацієнти припинили прийом ацетилсаліцилової кислоти та статинів, 1 - клопідогрелю та 6 - метаболічних препаратів (вітамінів групи В та вітаміну D).

Дані анкетування пацієнтів 1-ї групи за кожним із компонентів опитувальника SF-36 при госпіталізації та через 6 і 12 міс після операції представлені в табл. 2. Як видно, середні показники ЯЖ хворих у доопераційний період значно відрізнялися від рівня ідеального здоров'я. Протягом дослідження відзначено достовірне покращення показників ЯЖ пацієнтів. Досягнуто достовірне поліпшення як фізичного, так і психологічного компонентів здоров'я пацієнтів по завершенню 6 та 12 міс спостереження.

Таблиця 2. Показники ЯЖ хворих 1-ї групи за опитувальником SF-36 (n=48)

\begin{tabular}{|c|c|c|c|}
\hline \multirow[b]{2}{*}{ Показник } & \multicolumn{3}{|c|}{ Бали, M $\pm m$} \\
\hline & $\begin{array}{c}\text { до } \\
\text { лікування }\end{array}$ & через 6 міс & $\begin{array}{l}\text { через } \\
12 \text { міс }\end{array}$ \\
\hline Фізичне функціонування & $31,25 \pm 2,64$ & $56,64 \pm 2,84$ & $78,8 \pm 3,72^{*}$ \\
\hline $\begin{array}{l}\text { Рольове функціонування, зумовлене } \\
\text { фізичним станом }\end{array}$ & $40,48 \pm 3,74$ & $70,41 \pm 5,22$ & $88,87 \pm 4,79^{*}$ \\
\hline Інтенсивність болю & $51,78 \pm 2,17$ & $64,71 \pm 2,75$ & $71,25 \pm 2,63^{\star}$ \\
\hline Загальний стан здоров'я & $32,54 \pm 1,84$ & $58,83 \pm 3,74$ & $73,68 \pm 4,74^{*}$ \\
\hline Життєва активність & $29,14 \pm 1,83$ & $54,78 \pm 2,79$ & $69,72 \pm 2,61^{*}$ \\
\hline Соціальне функціонування & $48,69 \pm 2,23$ & $57,90 \pm 2,67$ & $69,02 \pm 2,08$ * \\
\hline $\begin{array}{l}\text { Рольове функціонування, зумовлене } \\
\text { емоційним станом }\end{array}$ & $38,17 \pm 3,87$ & $57,81 \pm 3,84$ & $64,97 \pm 3,69^{*}$ \\
\hline Психологічне здоров'я & $36,15 \pm 1,87$ & $48,86 \pm 2,45$ & $75,45 \pm 2,94^{*}$ \\
\hline
\end{tabular}

При цьому рівень ГЦ достовірно знижувався та досягнув референтних значень у 64,6\% пацієнтів через 3 міс лікування. Відзначено достовірне підвищення рівня вітаміну D (середні показники - 36,92 $\pm 7,90$ нг/мл) через 6 міс лікування. Протягом 12 міс лікування досягається стабілізація показників рівня ГЦ та вітаміну D.

Спеціальних досліджень щодо впливу метаболічної терапії на ЯЖ пацієнтів із порушенням метаболізму вітаміну D та ГЦ після АКШ, за даними зарубіжної та вітчизняної літератури, не проводили, тому отримані нами результати складно зіставити з результатами інших досліджень.
При цьому в проведеній нами роботі показано, що у пацієнтів після АКШ, які отримували додатково метаболічну терапію, зазвичай не виникало рецидивів стенокардії, а поліпшення яЖ зберігалося як в ранні, так і у віддалені терміни (до 3 років спостереження) після АКШ.

У пацієнтів 2-ї групи ( $n=6)$ спостерігали рецидив стенокардії на тлі відмови від застосування призначених препаратів. Анкетування за допомогою опитувальника SF-36 проводили при зверненні та через 18ะ7,4 міс після оперативного втручання (табл. 3).

Таблиця 3. Показники ЯЖ хворих 2-ї групи за опитувальником SF-36 (n=6)

\begin{tabular}{|c|c|c|}
\hline \multirow{2}{*}{ Показник } & \multicolumn{2}{|c|}{ 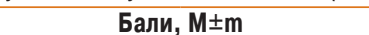 } \\
\hline & до лікування & через 6-36 міс \\
\hline Фізичне функціонування & $31,27 \pm 2,68$ & $35,12 \pm 2,82^{*}$ \\
\hline $\begin{array}{l}\text { Рольове функціонування, зумовлене } \\
\text { фізичним станом }\end{array}$ & $41,68 \pm 3,74$ & $44,87 \pm 3,69^{\star}$ \\
\hline Інтенсивність болю & $52,55 \pm 3,67$ & $55,15 \pm 3,47^{\star}$ \\
\hline Загальний стан здоров'я & $33,77 \pm 2,36$ & $36,48 \pm 2,84^{*}$ \\
\hline Життєва активність & $31,12 \pm 1,72$ & $33,62 \pm 1,31^{*}$ \\
\hline Соціальне функціонування & $48,66 \pm 3,13$ & $51,72 \pm 3,37^{*}$ \\
\hline $\begin{array}{l}\text { Рольове функціонування, зумовлене } \\
\text { емоційним станом }\end{array}$ & $37,14 \pm 3,77$ & $36,27 \pm 3,72^{*}$ \\
\hline Психологічне здоров'я & $32,14 \pm 2,37$ & $35,15 \pm 2,29$ * \\
\hline
\end{tabular}
${ }^{*} p<0,05$.

Як видно з табл. 3, у пацієнтів 2-ї групи як в доопераційний, так і у віддалений періоди, показники ЯЖ значно відрізнялися від рівня ідеального здоров'я. Найбільш значуще були порушені показники психічного здоров'я, фізичного функціонування та сфери соціальних взаємин. При детальному аналізі пацієнти скаржилися на больовий синдром, погіршення стану, незважаючи на проведену операцію. Також вони відзначали, що при виписці зі стаціонару самопочуття було кращим, ніж тепер.

Виявлено, що основними факторами, що призводять до рецидивів стенокардії у віддалені терміни після АКШ, у цих хворих $є$ дисліпідемія, ГГЦ, дефіцит вітаміну D у результаті відмови від прийому препаратів. Рівень ГЦ у цій групі достовірно підвищився

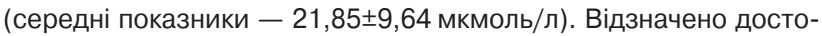
вірне зниження рівня вітаміну D (середні показники $19,67 \pm 6,43$ нг/мл).

Таким чином, наше дослідження показало достовірне покращення ЯЖ і хорошу ефективність застосування вітамінних препаратів у пацієнтів із порушенням метаболізму вітаміну D та ГЦ після АКШ.

\section{Висновки}

1. У пацієнтів після АКШ опитувальник SF-36 може забезпечувати надійну та сприйнятливу оцінку ЯЖ.

2. Пацієнтам, які перенесли хірургічне втручання на судинах серця, необхідна корекція метаболічних порушень та порушень ліпідного обміну.

3. Починати корекцію метаболічних порушень потрібно відразу після операції.

\section{Конфлікт інтересів}

Конфлікт інтересів відсутній.

\section{Список використаної літератури}

Гандзюк В.А. (2014) Аналіз захворюваності на ішемічну хворобу серця в Україні. Укр. кардіол. журн., 3: 45-52.

GBD 2015 Mortality and Causes of Death Collaborators (2016) Global, regional, and national life expectancy, all-cause mortality, and cause-specific mortality for 249 causes of death, 1980-2015: a systematic analysis for the Global Burden of Disease Study 2015. Lancet, 388(10053): 1459-1544. doi: 10.1016/S0140-6736(16)31012-1.

Montalescot G., Sechtem U., Achenbach S. et al. (2013) 2013 ESC guidelines on the management of stable coronary artery disease: the Task Force on the management of stable coronary artery disease of the European Society of Cardiology. Eur. Heart J., 34(38): 2949-3003. doi: 10.1093/eurheartj/eht296.

Ware J.E., Snow K.K., Kosinski M., Gandek B. (1993) SF-36 Health Survey Manual and Interpretation Guide. The Health Institute, Boston, MA.

Windecker S., Kolh Ph., Alfonso F. et al. (2014) 2014 ESC/EACTS Guidelines on myocardial revascularization: The Task Force on Myocardial Revascularization of the European Society of Cardiology (ESC) and the European Association for Cardio-Thoracic Surgery (EACTS) Developed with the special contribution of the European Association of Percutaneous Cardiovascular Interventions (EAPCI). Eur. Heart J., 35(37): 2541-2619. doi: 10.1093/eurheartj/ehu278. 


\section{Оценка качества жизни \\ пациентов с ишемической болезнью сердца с нарушением метаболизма витамина D и гомоцистеина \\ в отдаленный послеоперационный период после аортокоронарного шунтирования}

А.С. Никоненко, А.А. Никоненко, К.О. Чмуль, В.В. Осауленко

Резюме. Цель - оценить динамику качества жизни пациентов с ишемической болезнью сердца с нарушением метаболизма витамина D и гомоцистеина после аортокоронарного шунтирования (АКШ). Объект и методы исследования. АКШ проведено 126 пациентам с ишемической болезнью сердца. Опросник качества жизни SF-36 пациенты заполняли при поступлении и через 6 и 12 мес после операции. Результаты. У пациентов после АКШ, получавших дополнительно метаболическую терапию, как прави ло, не возникало рецидивов стенокардии, улучшение качества жизни сохранялось как в ранние, так и отдаленные сроки (до 3 лет наблюдения). У пациентов с рецидивом стенокардии после АКШ как в дооперационный, так и в отдаленный периоды, показатели качества жизни значительно отличались от уровня идеального здоровья. Наиболее значимо нарушены были показатели психического здоровья, физического функционирования и сферы социальных взаимодействий. Выводы. У пациентов после АКШ опросник SF-36 может обеспечивать надежную и восприимчивую оценку качества жизни. Пациентам, перенесшим хирургическое вмешательство на сосудах сердца, необходима коррекция метаболических нарушений и нарушений липидного обмена. Начинать коррекцию метаболических нарушений следует сразу после операции.

Ключевые слова: ишемическая болезнь сердца, гомоцистеин, витамин D, аортокоронарное шунтирование, SF-36.

\section{Evaluation of the quality of life in patients with coronary heart disease with impaired metabolism of vitamin D and homocysteine in the remote postoperative period after coronary artery bypass grafting \\ O.S. Nykonenko, A.O. Nykonenko, K.O. Chmul, V.V. Osaulenko}

Summary. Objective - to assess the dynamics of the quality of life in patients with coronary heart disease with impaired metabolism of vitamin D and homocysteine after coronaryartery bypass grafting(CABG). Materials and methods. $C A B G$ was performed on 126 patients with coronary heart disease. Patients completed the SF-36 quality of life questionnaire upon admission to the department and after 6 and 12 months after surgery. Results. In patients after CABG who received additional metabolic therapy, as a rule, there were no relapses of angina pectoris, improvement in the quality of life persisted both in the early and long-term periods (up to 3 years of follow-up). In patients with recurrent angina pectoris after $C A B G$, both in the preoperative and in the long-term periods, the quality of life indicators significantly differed from the level of ideal health. The most significantimpairments were indicators of mental health, physical functioning and social relations sphere. Conclusions. In patients after CABG, the SF-36 questionnaire can providea reliable and sensitive assessment of quality of life. Correction of metabolic disorders and lipid metabolism disorders is essential for patients who have undergone surgery on the heart vessels. Correction of metabolic disorders should be started immediately after surgery.

Key words: coronary heart disease, homocysteine, vitamin $D$, coronary artery bypass grafting, SF-36.

Адреса для листування:

Чмуль Карина Олегівна

69000 , Запоріжжя, просп. Маяковського, 26

Запорізький державний медичний університет, кафедра госпітальної хірургії

E-mail: olegovnakarina666@gmail.com

Одержано 11.11.2020 